\title{
THE PROPERTISATION OF TRADITIONAL KNOWLEDGE: SEEKING A BASIS IN THE SHARI'AH
}

\author{
Ibrahim Kayode Adam*
}

\begin{abstract}
This paper seeks to examine the implications of the propertisation of traditional knowledge from the Islamic law point of view. It proceeds on the premise that absence of direct Islamic legal ruling on the subject does not foreclose the chances of evaluating the modern protection policies from the Shari'ah context. It is argued that certain Shari' ah principles can be suitably adapted to justify the protection of traditional knowledge and address the needs of its holders. It finds, among others, that the nature of traditional knowledge as oral knowledge transmitted from one generation to another simply illustrates the original perception of knowledge in Islam and is thus qualified to be regarded as such. Further, while all knowledge belongs to Allah, Islam does not preclude the status of man as developer of new utilities for knowledge use. Therefore, holders of traditional knowledge deserve to be accorded recognition and primacy for their contributions to the conservation and sustainable use of the global biodiversity. The
\end{abstract}

Lecturer, Dept. of Business Law, Faculty of Law, University of Ilorin, Nigeria. E-mail: adam_kayus2003@yahoo.com. 
paper concludes that there is evidence to support the recognition of traditional knowledge, being a variant of manfa'ah as a form of al-māl (property) worthy of protection.

Keywords: al-māl, cultural heritage, intellectual property, manfa'ah, misappropriation, moral right, profit, propertisation, recognition and respect, secret knowledge, traditional knowledge.

\title{
PENGHARTAAN ILMU TRADISIONAL: MENCARI ASAS DALAM SYARIAH
}

\begin{abstract}
ABSTRAK
Makalah ini mencari untuk meneliti implikasi penghartaan ilmu tradisional dari pandangan undang-undang Islam. Ia bermula atas dasar bahawa ketiadaan peraturan undang-undang Islam secara langsung tentang tajuk ini tidak menutup peluang untuk menilai polisi perlindungan moden dari konteks Syariah. Dihujahkan bahawa prinsip Syariah tertentu boleh disesuaikan untuk mewajarkan perlindungan ilmu tradisional dan memberi perhatian kepada keperluan penyandangnya. Ia mendapati, antaranya, bahawa sifat ilmu tradisional sebagai ilmu lisan yang disampaikan dari satu generasi ke generasi yang lain memang mengilustrasi tanggapan asal terhadap ilmu dalam Islam dan dengan demikian layak dianggap begitu. Selanjutnya, walaupun semua ilmu itu milik Allah, Islam tidak menghalang status manusia sebagai pemaju utiliti baru untuk kegunaan ilmu. Oleh sebab itu, penyandang ilmu tradisional berhak diberi pengiktirafan dan keutamaan untuk sumbangan mereka kepada pemuliharaan dan penggunaan mapan biokepelbagaian. Makalah ini menyimpulkan bahawa terdapat keterangan untuk
\end{abstract}


menyokong pengiktirafan ilmu tradisional, selaku satu kelainan manfaat sebagai satu bentuk harta yang selayaknya dilindungi.

Kata kunci: harta, warisan budaya, harta intelek, manfaat, pelesapan, hak moral, keuntungan, penghartaan, pengiktirafan dan penghormatan, ilmu rahsia, ilmu tradisional.

\section{INTRODUCTION}

The search for effective protection of traditional knowledge has given rise to legal policies seeking to propertise the subject. The opponents of propertisation have argued that traditional knowledge lacked the features of a property and ought merely to be preserved for common access by all. However, the propertisation policy appears to be gaining wide acceptance among national policy makers, including those of Muslims countries in the Middle East, Africa and Asia. ${ }^{1}$ Thus, it becomes imperative to examine the Sharī ah status of such a policy.

This paper therefore examines the propertisation policy from the perspective of Islam's Sharī'ah despite the absence of legal rulings or models that address the protection of traditional knowledge under the Sharī'ah. It is argued herein that certain Sharī‘ah principles can be suitably adapted to justify the protection of traditional knowledge and address the needs of its holders. This approach is adopted in order to examine the status of Islamic Law that readily aligns with the protection of traditional knowledge.

\section{THE NATURE AND SCOPE OF TRADITIONAL KNOWLEDGE}

Traditional knowledge is generated, held and transmitted orally from one generation to another. This distinctive mode of transmission underlies its

$\overline{1} \quad$ See recent reports of the Inter-Governmental Committee of the World Intellectual Property Organisation on Protection of Genetic Resources, Traditional Knowledge and Traditional Cultural Expressions in for example document WIPO/GRTKF/IC/9/INF/4; WIPO/GRTKF/IC/9/INF/ 5; and WIPO/GRTKF/IC/19/4. 
recognition as an alternative category to dominant global knowledge systems. However, the oral nature of traditional knowledge does not present any serious problems for its recognition under the Islamic Law because in Islam, knowledge is originally held and transmitted orally. It is significant that the Glorious Qur'ān, the message of Islam was orally transmitted to the Holy Prophet Muhammad (SAW) who passed the message to his companions and the first generation of Muslims in the same way. ${ }^{2}$ There are other specific examples of recognized oral Islamic knowledge which include:

- $\quad$ The knowledge of Hadith and Sunnah which was originally committed to memory and transmitted orally in the early history of Islam;

- $\quad$ According to a narrative by the Qur'ann, the approved Islamic method of burial whereby the corpse is hidden underground originally derives from Qābilah’s (Cain's) oral encounter with the raven that showed him how to bury the corpse of his deceased brother Ḥābilah (Abel). ${ }^{3}$

This recognition remains despite the present reality that Islamic knowledge has become largely associated with printed materials. The foregoing examples provide a basis to argue that the recognition of oral traditional knowledge is consistent with the principles and practice of the Sharīah. However, such recognition of oral traditional knowledge is not synonymous with recognition of property rights of its holders.

\section{THE NATURE OF RIGHTS PROTECTED}

Protection of traditional knowledge seeks to recognise certain rights of the knowledge holders. These consist of: (i) the right to control access to and use of the knowledge and receive reward or compensation for its

2 See Qur'ān, Al-An 'ām: 7, where Allah states that: If we had sent unto thee a written (Message) on parchment, so that they could touch it with their hands, the unbelievers would have said: "This is nothing but an obvious magic!”

3 Qur'ān, Al-Maidah: 27-31. 
utilisation; (ii) the right of holders to recognition and respect for the contributions made by their traditional knowledge.

\section{(i) Right to control access and receive rewards}

The right to control access to and receive rewards from traditional knowledge is proprietary in nature. In Islamic law, proprietary rights are conferred on owners of property ( $(a l-m \bar{a} l)$ to exclusively use their property or grant permission to others to do so in exchange for reward, compensation or other payments or as they may otherwise desire in accordance with the Sharī'ah. The rights are established in the Qur' $\bar{a} n$ as follows:

"O ye who believe! Eat up not your property among yourselves in vanities: but let there be amongst you traffic and trade by mutual good-will: nor kill (or destroy) yourselves: for verily Allāh hath been to you Most Merciful."4

The Prophet emphasized the importance of property rights in his Farewell sermons that: "Nothing shall be legitimate to a Muslim which belongs to a fellow Muslim unless it was given freely and willingly.” $\mathrm{He}$ states further that: "Verily, your blood and your property are as sacred and inviolable as the sacredness of this day of yours, in this month of yours, in this town of yours." ${ }^{5}$

In the discussion of proprietary rights in Islam, it is important to examine rights over traditional knowledge in relation to the concepts of al-māl (property) and al-milkiyyah (ownership).

\footnotetext{
$4 \quad$ Qur'ān al-Nisai: 29.

5 See, Mumtazu al-Muhadithun Muhammad Ubayd Al-Akbar, The Orations of Muhammad (The Prophet of Islam (SAW)), (New Delhi: Kitab Bhavan, $4^{\text {th }}$ edn., 1991), at 75.
} 


\section{Traditional knowledge and Nature of Property (al-māl)}

The word al-māl literally refers to anything that can be owned, whether physical objects ('ayn) or benefits (manfa $a$ ah) ${ }^{6}$ However, Islamic jurists hold diverse views on the technical application of the term. To the Hanafis, $a l-m \bar{a} l$ is confined to physical objects that are desirable. ${ }^{7}$ According to Ibn 'Âbidîn, the term refers to everything towards which human instinct is inclined that can be stored or saved for a time of need. ${ }^{8}$ Since storability and desirability are essential characteristics of something to be protected under this school, intangible property is unqualified for protection. Thus, according to the Hanafī school, manfa' $a h$ (usufruct) does not qualify as $a l-m \bar{l} l$ since it can only be used or consumed. According to this view, use or consumption results in extinction rather than possession. Thus, manfa' $a h$ is non-existent and cannot be possessed, so it is not al-māl. ${ }^{9}$

It is significant to note that despite this position, the school sometimes justifies transactions involving manfa 'ah on other grounds. For instance, the school accepts that manfa'ah can be a subject of milkiyyah through the application of istihsan. By implication, it is recognized as al-māl in such a circumstance. Thus, the school holds that when the property of an orphan or waqf property has been unlawfully appropriated, any enjoyment and exploitation thereof should be duly compensated. ${ }^{10}$

The other schools, comprising Mālikī, Shāfi 'ī and Hanbalîs, treat manfa $a h$ as al-māl which is capable of infringement. Their definitions and application of the term seem to have been informed by the following considerations:

6 Abū Zahrah Maḥmūd, Al-Milkiyyah wa Naẓariyyat Al- 'aqd fi Sharī‘at al-Islāmiyyah,(Dār al-Fikr al-' Arābī, 1416AH/1996BC), at 47.

$7 \quad$ Ibid, 53.

8 Muhammad Amīn Ibn 'Abidīn, Radd Al-Muhtār 'alā Al-Durri AlMukhtār Sharh Tanwīr Al-'abṣār, (Bayrūt: Dār al-Kitāb al-'Ilmiyyah, 1415H/1994) 7:10.

$9 \quad$ Abū Zahrah Maḥmūd, note 6 at 53.

10 Ida Madieha Abdul Ghani Azmi, "Basis for the Recognition of Intellectual Property in Light of the Shari'ah,” International Review of Industrial Property and Copyright Law, Vol. 27, No. 5, (1996): 649674. 
a) Manfa'ah is desirable, and people struggle towards it, seek it and invest to reap results from it. The basis of interest in a thing relates to benefits derivable from it rather than its physical nature. In fact, a physical object by itself is not worth the status of al$m \bar{a} l$ unless it is beneficial to its owner(s). Thus, anything that lacks benefit is not regarded as property because it is difficult to see how the idea of al-māl can ever be conceived without regard to the essence and cause of recognition. ${ }^{11}$

b) By general customs of trade and property transactions, benefit is regarded as al-māl (property). This leads to the conclusion of transactions such as contracts for hire and endowments. ${ }^{12}$

c) The legal approval of benefit as a proper means for settling mahr (marriage dowry) underscores its status as al-māl. It is significant to note that only al-māl can be used as marriage dowry in consonance with Allāh's words in the Qur'ān: “And all others are lawful, provided you seek (them in marriage) with gifts from your property, desiring chastity not fornication." ${ }^{13}$ The majority contend that the approval of a benefit as dowry, in the unanimous opinion of jurists, confirms that it is regarded as al$m \bar{a} l .^{14}$

However, it is found that discussions of manfa 'ah by the majority largely focus on intangible rights incidental to and derived from possession of tangible property. ${ }^{15}$ It has, however, been argued by some contemporary scholars that the term should "cover the usage of intangible rights, independent of their physical manifestation."16 This position is justified based on the loose definition of manfa 'ah in the majority view "as anything which has value." They argue against restricting manfa 'ah to benefits attached to physical property and that it should extend to other benefits, such as intellectual property, which are exploited

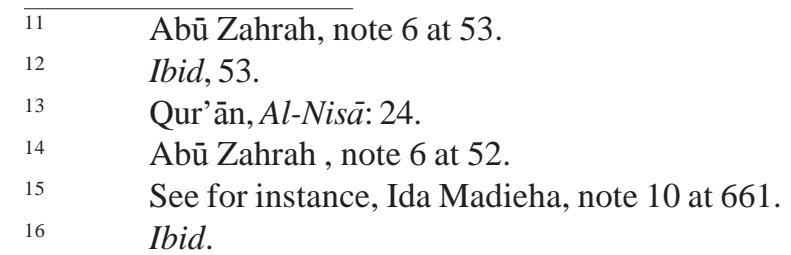


independent of their physical origin. The arguments can be summarized as follows:

(i) Manfa 'ah loosely means anything which has value;

(ii) Although intellectual ideas are separate and independent from corporeal objects by which they are expressed, the connection between an idea and its origin is analogous to the connection between rights to usufruct or benefits from tangible property when separated from its source;

(iii) Utility is the essential element or effect of manfa 'ah;

(iv) Whereas physical objects are a source of benefits from physical property, human intellect is the source or origin of intellectual output;

(v) The case for protection of intellectual property is strengthened by the temporary (tawqit) nature of the subject and its confinement to a particular duration, place and circumstances. ${ }^{17}$

One fatwa (singular for fatāwa a, legal opinions or rulings issued by notable Islamic scholars), ${ }^{18}$ summarizes the implications pertaining to intellectual property as follows:

a) Intellectual property rights are legitimate and are owned by the researcher, worker or translator;

b) It is not proper to transgress against the holder's rights;

c) If some financial benefits accrue from such intellectual property, the holder is more entitled to it than anyone else;

\footnotetext{
Ibid at 662.

18 Shaykh Muhammad Baazmool, Bakkah Questions and Answers Net online (accessed 6 Jan. 2011) at <http://bakkah.net/interactive/q\&a/ aamb080-copyrights-translations-intellectual-property.htm>
} 
d) It is unlawful to use intellectual property belonging to a person without obtaining his prior permission. In addition, a reproduction of the work must be precise and the holder must be duly and properly acknowledged;

e) Others may only publish the work in a way that is pleasing to the holder. ${ }^{19}$

But the question is whether the foregoing treatment of intellectual property covers or extends to traditional knowledge. It shares the characteristics of intellectual property as an intangible asset that lacks permanence and tangibility. Thus, the above argument in support of intellectual property ordinarily qualifies as a response to any question about the status of traditional knowledge as al-mal. Furthermore, the analogy of source or origin of benefit and elements of utility, which qualifies intellectual property as manfa'a, are similarly present in traditional knowledge. Whereas human intellect and efforts are considered the origin or source of intellectual property, in traditional practice, the cultural heritage and group efforts of the local people qualify as the origin or source of traditional knowledge. Whereas it is widely accepted that traditional knowledge is embodied and embedded within a people's body of tradition, consequently therefore, the Islamic treatment of intellectual property also covers traditional knowledge and qualifies it as manfa 'ah, and as recognizable as al-māl under the Sharī'ah.

In effect, traditional knowledge holders, like their intellectual property counterparts, ${ }^{20}$ enjoy the rights of owners of intangible assets such as the right to personally exploit or permit others to enjoy their benefits. Thus, transactions involving payment of a consideration ( iwad ) such as leasing agreements (al-ijärah) or those devoid of any consideration as is the case of lending ( $\left.i^{\mathrm{c}} \overline{\mathrm{r}} \mathrm{rah}\right)^{21}$ can be adopted to permit others to enjoy the right.

\footnotetext{
$19 \quad$ Ibid.

20 Heba A. Raslan, "Shariah and the Protection of Intellectual Property: The Example of Egypt,” IDEA: The Intellectual Property Law Review, 47 IDEA (Franklin Pierce Law Centre, 2007): at 497.

$21 \quad$ Abū Zahrah, note 6 at70.
} 
However, to gain recognition under the Sharī $a h$, proprietary or financial right must have been procured by lawful means. Islam forbids profit without labour and prohibits maysir (gambling which generally extends to all easy profits). The question is whether traditional knowledge involves a sufficient investment of labour to justify any need to financially reward or compensate its holders. ${ }^{22}$ This question is discussed later in relation to acquisition modalities for rights to traditional knowledge.

\section{(ii) The Right of Holders to Recognition and Respect}

Recognition and respect for people of knowledge are important ideals in Islam. Imam al-Nawāwī in Riyad al-Ș̣älihìn ${ }^{23}$ highlights the need to show respect and give priority to people of knowledge based on the provisions of the Qur'ān and Sunnah. The Qur'ān states: "Say: Are those who know equal to those who do not know?" It is only men of understanding that receive admonition." 24 He also cites a number of Prophetic traditions to demonstrate recognition for scholars. For instance, Abū Mas'ūd Al-Ansāri (May Allāh be pleased with him) reported that the Messenger of Allāh (SAW) would place his hands upon our shoulders when we would form rows for al-Salät (the prayer) and say, "Stand in straight rows and do not differ among yourselves, or else your hearts will differ due to disaccord. Let those be nearest to me who are mature and endowed with understanding (of the religion), then those who are

$22 \quad$ There are a number of ahädith of the prophet (SAW) that place emphasis on the virtue of earnings through honest labour. For instance, one hadith states that the best income is the one earned honestly by the hard-working labourer. Similarly, one hadith states that: No one ate better food than the person who laboured with his own hands. See alBukhāri, al-Jāmi ' al-Sahīh, Arabic - English translated by Muhammad Muhsin Khan, (Lahore: Kazi Publications, $6^{\text {th }}$ ed., 1986), Vol. 3:34, at 162. AbdAllahi Muhammad Al-Darwīsh (ed.), (Bayrūt: Dar al-'Bayāriq, 1414H/1994), at 126.

24 Qur’ān, al-Zumar: 9. 
nearest to them in these respects and then those who are nearest to them." 25

Recognition of scholars has also been inferred from the verse of the Qur'ān which states that: “And whoever honours the sacred Rites of Allāh, for him it is good in the sight of his Lord."26 Expounding the verse in a recent fatwa, ${ }^{27}$ Shaykh Hishām Kabbānī notes that scholars are, after the Prophets, among the greatest symbols of Allāh on earth. He states that the right of scholars to recognition should not be infringed because the Prophet warned that: "Whoever does not know the rights of our scholars is not a member of our community." ${ }^{28}$

Despite the emphasis on recognizing people who are knowledgeable in religion, it is submitted that the injunctions apply to persons knowledgeable in other fields including holders of traditional knowledge. This is because during the time of the Prophet (SAW), people around him consulted with scholars in a wide range of fields, including medicine and agriculture to obtain solution in relation to their problems. Hence, the Prophet (SAW) was reported to have encouraged believers to "seek knowledge to the depths of China," ${ }^{29}$ which was not known to have a Muslim population at the time. This confirms that Islam

$25 \quad$ Muslim Abū al-Ḥusayn ibn al-Ḥajjaj al-Nīshābūrī, Șaḥ̄ḥ Muslim, Arabic-English, Abdul Hamīd Siddiqī (trans), (India: Adam Publishers, 1999), vo.1-A: 28, at 267. The book contains another narration: 'Abdullah bin Mas'ud (May Allah be pleased with him) reported: Messenger of Allah (PBUH) said, "Let those be nearest to me in Salat (prayer) who are mature and possess (religious) knowledge, then those who are nearest to them in these respects." He repeated this three times and then added, "Beware of indulging in the loose talks of the markets (when you are in the mosque)."

26 Qur'ān, al-Hajj: 30. In verse 32, this exhortation is repeated that "and whoever holds in honour the rights of Allāh, (in the sacrifice of animals), such honour should come truly from the piety of the heart."

27 The view was expressed by Shaykh Hishām Kabbānī in his fatwa which states that kissing the hand of a scholar is Sunnah. The fatwa is available online at http://www.themodernreligion.com/misc/hh/kissingscholar hand.html, (accessed January 23, 2011).

28 This Hadith was authenticated by Albani in his Sahih Al-targhib, (Bayrūt: Dār Ihyā-ut Turāth al-'Arabī, 1417), 1:44.

29 Al-Majlisī Muhammad Baqri, Biḥārul Al’Anwār, (Bayrūt: Dār...., 1983.).1:177. The Hadith has been widely criticized as weak. 
recognizes and guarantees respect for holders of valuable knowledge for its utility to humanity. Hence, such recognition cannot exempt traditional knowledge holders whose contribution to global development is widely acknowledged.

Islam also established the right to attribute information to its source and acknowledge its contributors. In the early centuries of Islam after the demise of the Prophet (SAW), the acknowledgment of information sources or chains of transmitters (Isnad) was a major device employed to preserve and authenticate hadith and Sunnah. In addition, the Ijazah system involved the exhibition by students of certificates of permission to disseminate knowledge held by their masters. This was a form of acknowledgement of the source of knowledge. ${ }^{30}$ The same system has been applied to justify the moral right of acknowledgement for copyright owners in Islam. ${ }^{31}$ It is instructive that knowledge of ahädith and knowledge disseminated under the Ijazah system makes no distinction between oral or written transmission of knowledge. The flexible application of this culture of attribution across generations provides good opportunity for recognizing traditional knowledge attribution to its holders and acknowledgement when their traditional knowledge is used.

Furthermore, the concern about integrity of traditional knowledge and its holders is familiar to Islam. Muslims have fundamental concerns for the integrity of Islam and its major knowledge sources, particularly the Qur'ān and Sunnah. 'Alī Khan identifies three main devices that are used to safeguard the integrity of Islam as protected knowledge. ${ }^{32}$ These comprise: (i) rules that mandate the study and understanding of the protected knowledge; (ii) rules that outlaw innovations (bid'a) that

$30 \quad$ For further reading on Ijāzah, see Shahab Ahmed; "Mapping the World of a Scholar in Sixth / Twelfth Century Bukhara: Regional Tradition in Medieval Islamic Scholarship as reflected in a Bibliography,” Journal of American Oriental Society, Vol. 120 No. 1 (Jan-Mar 2000): 24-4, available online vide JSTOR at: <http://www.jstor.org/stable/604883> (accessed 5 Mar 2009).

31 Ida Madieha A. Azmi, "Authorship and Islam in Malaysia: Issues in Perspective," International Review of Industrial Property and Copyright Law, Vol. 28, No. 5 (1997): 672, 675.

'Ali Khan, "Islam as Intellectual Property "My Lord! Increase Me in Knowledge," Cumberland Law Review, Vol. 31, (2000-2001): 361 available online vide SSRN at <http://ssrn.com/abstract=936291> (accessed 8 June 2009). 
compromise the integrity of its protected knowledge; (iii) imposition of punishment against Muslims who repudiate the integrity of the knowledge by distorting or circulating falsehood (ridd'a). ${ }^{33}$

As a demonstration of the seriousness of the integrity of Islamic knowledge for Muslims, Allāh says: "Who doth more wrong than one who invents a lie against Allāh, or said: 'I have received inspiration,' when he hath received none." 34 The Prophet is similarly quoted as saying that: "Ascribing false things to me is not like ascribing false things to anyone else. Whosoever tells a lie against me intentionally then surely let him occupy his seat in Hell-Fire.”35 The integrity of other Islamic sources is also preserved, including the doctrinal decisions of past scholars which are regarded as guidance for present and future generations.

Furthermore, innovations that contradict or pervert established tenets or perceptions of Islamic faith are serious deviations prohibited by Islamic Law. Members of the faith are free to improve their understanding of the religion but cannot pervert the faith by introducing innovations in the guise of such improvement. Public repudiation or pronouncements capable of reducing the public's esteem for Islam (ridda or apostasy) is prohibited as a grave offence against the religion. The Qur'ān states that apostates are "those who purchase a small gain at the cost of Allāh's Covenant and their oaths." Ali Khan likens apostates to a corporate insider who discloses the secrets he has undertaken to protect; or a state official who turns traitor and joins the ranks of the enemy; or a custodian who destroys the very monument he was safeguarding on behalf of the community. ${ }^{36}$

There seems to be a close similarity between the concerns addressed by the Islamic law and those of traditional knowledge holders and it is therefore not difficult to extend the same type of right to traditional knowledge holders. It is irrelevant that the rights were only recognized in relation to religious knowledge under Islamic law. This is because, as mentioned earlier, Islamic law treats all fields of knowledge as important. For instance there is evidence in the history of Islamic law to show that

\footnotetext{
$33 \quad$ Ibid.

34 Qur'ān, al-An'am: 93.

35 See Al-Bukhārī, Al-Jāmi` Al-Sahīh, Arabic - English translated by Muhammad Muhsin Khan, (Lahore: Kazi Publications, ${ }^{\text {th }}$ ed., 1986), 1 : 83.

$36 \quad$ See 'Ali Khan, note 32 at 365.
} 
the practice of ensuring attribution and integrity of knowledge through the Ijazah system was adopted in other areas of knowledge, especially medicine. ${ }^{37}$ It is similarly insignificant that traditional knowledge holders may be non-Muslims because protection under the Shari'ah extends to all regardless of faith, nationality or gender. Thus, there can be no objection to the people's right vis-a-vis protection of their knowledge. Their sacred knowledge deserves to be safeguarded from corruption or misuse. This conclusion seems to enjoy support under the following verse of the Qur'ān:

O ye who believe! Let not some men among you laugh at others. It may be that the (latter) are better than the (former): Nor let some women laugh at others: it may be that the (latter) are better than the (former): Nor defame nor be sarcastic to each other, nor call each other by (offensive) nickname: ill-seeming is a name connoting wickedness, (to be used of one) after he has believed: And those who do not desist are (indeed) doing wrong. ${ }^{38}$

\section{ISLAM: DEFENSIVE PROTECTION AND RESTRICTED ACTS}

Ideally, the protection under discussion defends traditional knowledge against certain acts and / or omissions and causes violators to incur liabilities. Wrongful acts and / or omissions in offense against traditional knowledge are commonly classified as 'restricted acts' or broadly described as ‘misappropriation' by protection instruments.

In general, when acts or omissions are inconsistent with the rights as discussed earlier, they are classed as wrongful misappropriation and deemed liable for redress. This consequence is also implied under the Shari ${ }^{\prime} a h$ in relation to a violation of the rights reserved for people of knowledge. The Sharī ah forbids all acts or omissions amounting to misappropriation, hence, the Holy Prophet (SAW) is reported to have

\footnotetext{
37 Quazi M. Iqbal; “Legacy of Islamic Medicine,” IKAU: Med. Science, Vol. 2 (1412AH/1992): at 27-31.

38 Al-Hujurat: 12.
} 
remarked that: "Trustworthiness causes one to be self sufficient (financially) and misappropriation causes poverty."

Furthermore, there are established legal devices that address acts or omissions that pose threats to the peaceful enjoyment of proprietary rights, including al-sharkat (theft) and others. All of these together are a form of 'negative' protection that affirms the extension of similar protection to traditional knowledge. However, it is not certain whether Shariāh punishments and remedies against theft or other wrongful appropriation of physical property are applicable to wrongs against intangible assets such as traditional knowledge. ${ }^{39}$ According to some contemporary views, ${ }^{40}$ crimes against intangible assets may attract disciplinary measures ( $t a{ }^{\prime} z \bar{r}$ ) but should differ from those prescribed for theft or damage of material property.

Furthermore, Islam frowns against unjust enrichment (khayyānah or cheating). This device protects property against all forms of unjust appropriations such as bribery, cheating and the like. The Prophet (SAW) is reported to have remarked: "He who cheats is not of us. Deceitfulness and fraud are things that lead one to hell." ${ }^{41}$ The person

$39 \quad$ One commentator notes that "hadd" punishment by which the hand of a thief is amputated does not apply where a thief steals a book where the intention is not to steal the book as paper, but the idea in it. See Richard E. Vaughan, "Defining Terms in the Intellectual Property Protection Debate ...,” as cited by Amir Khouyri; “Ancient and Islamic Sources of Intellectual Property in the Middle East” IDEA: The Journal of Law and Technology 43 IDEA (2003), 151 at 200, retrieved online vide LexisNexis at: http://www.lexisnexis.com/us/lnacademic/search/ journalssubmitForm.do, (retrieved 27 Jan. 2010).

$40 \quad$ Since the ruling on Traditional Knowledge (TK) is likely to follow that of its Intellectual Property (IP) counterpart, the various fat $\bar{a} w \bar{\imath}$ made in respect of intellectual theft become relevant. For these, see fatwa on intellectual theft issued by Group of Muftis on 28 ${ }^{\text {th }}$ Sept. 2004. The fatwa $\bar{a}$ cites other fatāw $\bar{\imath}$ such as the one issued by Al-Azhar Fatwa Committee on the same subject; fatwā by Shaykh Muhammad Husayn Faḍl Allāh, a well known Shiite jurist in Lebanon; and fatwā by Dr. Zaki Badawi, Director, Muslim College, London, among others. The fatwā is online at www.islamonline.net.English-Ask_Scholar/Fatwa, (accessed 15 Jan. 2010).

$41 \quad$ In another narration: “A man mentioned to the Prophet that he had always been cheated in bargains. The Prophet (SAW) said, 'When you ever bargain, say, 'no cheating.'”Al-Bukhārī, Al-Jāmi' Al-Sahīh, Arabic-English, Vol. 9:94. 
who takes the asset of another by deceit does not become the owner and does not have the right to use it. Instead, he becomes a trustee thereof and would be required to pay ta ' wi $d$ (compensation) for all profits made from the utilization of the property. ${ }^{42}$ In effect, the Shari ${ }^{\top} a h$ provides scope for the implementation of rules against unfair competition, unjust enrichment, deceptions and all forms of trade malpractices affecting traditional knowledge. One advantage of this approach is that it is not specifically designed for trade activities and can therefore serve to protect traditional knowledge against all forms of deceit even where profit is not intended by the defaulter.

One of the key concerns of traditional knowledge holders is that their secret traditional knowledge should not be disclosed. This raises the question whether legal devices intended for safeguarding the secrecy of traditional knowledge can be consistently implemented under the Sharī'ah.

Generally, Islam maintains a negative attitude towards the concealment of knowledge because the act is considered sinful. This seems largely connected to important premium that Islam attaches to knowledge as a tool for social and spiritual development. There are several injunctions against the concealment of knowledge in the Qur'ān ${ }^{43}$ and Sunnah, but these largely relate to religious knowledge and actions. As Ida Madieha notes, the generalisation of the rules against concealment results from the broad connotation of the word 'ilm (used in the injunctions). This ensures the application of the rules to all types of knowledge without distinguishing between religious knowledge and other sciences.

The evil of concealing knowledge is underscored in the hadith of the Prophet which states that: "Whoever is asked about ' $\mathrm{ilm}$, which he learns and conceals, will be lashed with the bridle of fire from hell" 44 However, scholars have argued that the rule against concealment of knowledge is not a rule of general application. They argued that it is necessary to examine the effective cause of the prohibition to determine

\footnotetext{
42 Amir H. Khoury; “Ancient and Islamic Sources of Intellectual Property...,” at 178.

43 See for instance, Qur'ān, al-Baqarah: 42; 240 and 246.

44 Annas bin Mālik, Al-Musnad Jāmi'u Bashar 'awād Ma'rūf (ed.), (Baghdad, Matba'ah Al-Awqāf wal-Shu’uni al-Dīniyyah, 1406/1986), 2:32.
} 
its scope of application. ${ }^{45}$ For instance, Ida Madieha identifies two separate causes ('illah) for the prohibition of concealment of knowledge. The first 'illah (effective cause) of the prohibition is the 'concealment of knowledge' itself and not prohibition of 'transactions' involving knowledge. ${ }^{46}$ The second is that any concealment of knowledge may lead to falsehood or telling lies, which is sinful. ${ }^{47}$ It follows from the second 'illah that the prohibition is unrelated to secret traditional knowledge which has nothing to do with perpetrating falsehood or lies. Rather, its secrecy is maintained to preserve its integrity through the holder's control of access to it.

Furthermore, Islam recognises the responsibilities of knowledge holders as Allāh's trustees in relation to His bounties entrusted to their possession. Hence, they are required to maintain the effective control of access to their knowledge. Similar responsibilities are attached to other forms of gifts from Allāh, including physical property. Warning Muslims against careless attitudes regarding their possessions, the Qur'ān states:

And to those weak with understanding, give not your property which Allāh has assigned to you to manage. But feed and clothe them therewith, and speak to them words of kindness and justice. ${ }^{48}$

According to a commentary, the wording of the verse is perfectly general despite its direct application to orphans. Thus, it defines property principles to include the responsibilities of property holders in order to ensure that their decisions take account of certain interests, including communal and family interests. ${ }^{49}$ The interests of neighbours, co-owners or joint owners, and the property itself, are crucial to any decision that

$45 \quad$ Ida Madieha, "Basis for the Recognition of Intellectual Property...," 651.

$46 \quad$ Ibid.

47 Ibid. In support of her suggestion, the author cites the hadith narrated by Ali that "the Prophet said to the effect: 'Do not tell a lie against me for whoever tells a lie against me (intentionally) then he will surely enter the Hell fire.'”

48 Qur'ān, al-Nisāi: 5.

49 Muhammad Yusuf Ali, The Holy Qur'an: English Translation of the Meanings and Commentary, (Lahore: 1934 \& 37), at 207. 
may grant access to a property. The Prophet (SAW) illustrated the adverse consequence of careless transmissions of knowledge in one hadith which states: "Seeking knowledge is obligatory on all Muslims. The one who gives knowledge to those who do not deserve it is like the one who puts fake jewels and gem on a pig's neck."50

Furthermore, a Muslim is entitled to keep certain information secret or to hold it as confidential. Confidential information refers to any non-public information that a party holds regarding his privacy, survival, family or other interests. Such secrecy may be motivated by certain interests that include the protection of reputation, livelihood or personality of the holder of the information. The Prophet is reported to have told Muslims to: "Take care of what is useful to you and seek assistance from Allāh.” Thus, when a Muslim believes that his image, business or personality depends on some information, he is entitled to shield it from public gaze or attention. However, nothing precludes the holder of certain information from disclosing it to persons of his choice. Thus, a recipient of secret information is considered to have a religious duty to maintain its secrecy. Divulging confidential information is so heinous that Islam considers it one of the attributes of a munāfiq (hypocrite). ${ }^{51}$

50 Zakiyyuddīn Abdul Azīm ibn Abdul Qawīyy Al-Munzirī, Al-Targhīb wa Al-Tarhīb min Al-Hadìth Al-Sharîf, (Bayrūt: Dār al-Kutub al'ilmiyyah, 1424H/2002), 1:52. The hadith is also cited in Ida Madieha, "Basis for the Recognition of Intellectual Property...," at 652. The learned writer refers to the tradition of Harīr ibn Salman ibn Samīr that: "Do not narrate falsehood to al-hukamä' (those possessing wisdom), do not narrate wisdom to al-sufahä' (people who are ignorant), for they will lie against you, do not conceal knowledge to those who deserve it for you will commit a sin, do not narrate it to those who do not deserve it, for you will become ignorant. Indeed you are obliged to observe the right in your knowledge as you are obliged to observe the right in your property." at 655.

51 In the hadith reported by Abu Hurairah (RTA), the Prophet said: The signs of the munāfiq are three. When he speaks, he lies. When he promises, he fails. When he is entrusted, he breaches the trust. In another report, Abd Allāh ibn Umar (RTA) narrates that the Messenger of Allāh (SAW) said: He in who there are four qualities is a total munäfiq. He in who there is one of these qualities has in him a quality of nifäq. This nifäq remains in him] until he shuns it. When he is trusted, he misappropriates; when he speaks, he lies; when he pledges, he betrays and when he disputes, he becomes abusive. 
In Islam, confidential information is not necessarily related to or held by an individual. It may be related to or held by a group. Thus, Jäbir narrated that the Prophet said:

"Gatherings are a trust, so he who attends should not reveal a talk except in matters that cannot be kept secret without causing detriment to Muslims.”

In another version narrated by Abu-Dāwūd:

"Gatherings are a trust except three: One in which blood is unlawfully shed, or an impermissible sex is permitted or a gathering where an unlawful property is unjustly taken.”

Therefore when confidential information is held at group level, its members are obliged to treat the information with utmost secrecy and as a trust, except where to do so leads to any clear violation of principles laid down by Islam. This seems to cover the customary responsibility of members of traditional knowledge holding groups to maintain the secrecy of their knowledge.

Traditional knowledge is often essential to local people because their economic and socio-cultural survival depend on it. Hence, any harm to the knowledge affects the holders' livelihood, image and reputation. It is therefore crucial that certain traditional knowledge considered vital to their livelihood and survival is maintained in secrecy to protect these essential interests. It is prejudicial therefore, to insist on the public disclosure of traditional knowledge. Public disclosure of sacred traditional knowledge may result in its perversion as well as cause harm to the holder(s). Also, public disclosure of secret traditional medicine may not only lead to free-riding and economic loss for the people, but could also undermine the holder's dignity and importance in the community. It is precisely such consequences that the Prophet sought to avert by counselling that Muslims should take good care of what is useful to them. Therefore, firm ground is established to argue that secret traditional knowledge constitutes an exception to the Islamic prohibition against the concealment of knowledge. 


\section{TRADITIONAL KNOWLEDGE AND MODE OF RIGHTS ACQUISITION IN ISLAM}

Honest labour is one of the approved modalities for the acquisition of property rights in Islam. This has support in both the Qur'ān ${ }^{52}$ and Sunnah. The Prophet (SAW) is reported to have placed great emphasis on the virtue of earnings through honest labour. For example, he reportedly said in one hadith that the best income is the one earned honestly by the hard-working labourer. He stated in a similar hadith that: "No one ate better food than the person who laboured with his own hands." Thus, 'amal (labour) is the recognized means for personal wealth creation under the Sharīah.

The principle clearly recognises the right of traditional knowledge practitioners such as native doctors to charge fees for services rendered to customers or patients by this example. However, the problem is whether they are justified to demand reward or compensation from parties who utilize their traditional knowledge. It has been argued that no person is entitled to receive property recognition for the natural value of resources endowed by God, ${ }^{53}$ except for improvements made thereupon by man. ${ }^{54}$ Some have argued that traditional knowledge is a gift of nature since it comprises a mere discovery of the properties of natural resources endowed by God. Others similarly argue that since all knowledge comes from God, traditional knowledge is 'a common heritage of mankind.' The effect of these arguments is that traditional knowledge should be subject to open and free access because its protection may cause a monopoly. Similar views rely on verses from the Qur'ān, particularly Allāh's pronouncement that: "He knoweth what (appeareth to His creatures) before or after or behind them." 55 But is it truly the case that traditional knowledge is the product of nature which is available to all?

Responding to similar arguments regarding the basis for the recognition of intellectual property in Islam, Ida Madieha notes that intellectual property is about the creation of a new utility rather than

\footnotetext{
52 For instance see Qur’an, al-Nisāi: 32.

53 John Cummings, Hussein Askani and Ahmad Mustapha, Islam and modern economic exchange, (Syracuse U Press, 1980), 34.

$54 \quad$ Amir H. Khoury, “Ancient and Islamic Sources of Intellectual Property Protection in the Middle East: A Focus on Trademark,” at 190.

55 Qur'ān, Al-Baqarah: 255.
} 
creation of new information. Thus, she posits that the above verse should not be understood as mandating compulsory sharing of knowledge. She contends further that the nature of knowledge should not be oversimplified by ignoring that human knowledge and capacities to learn it are influenced by certain factors including practical understanding, levels of awareness, experience, and one's range of information. She articulates these points as follows:

This view is rather simplistic, as on deeper analysis the above Qur'änic statement is not to be understood in the sense of compulsory sharing of information (in its widest meaning). Neither can it be understood to guarantee that everyone understands, absorbs and synthesizes information in the same manner. A person's knowledge varies according to one's practical understanding and is often influenced by awareness or familiarity gained by experience or a person's range of information. This is the purport of the Qur' annic statement in Surah al-Zumar: which means: "Say: Are those equal, those who know and those who do not know." 56

Thus, it is acknowledged in Islam that the totality of what is known originates from Allāh. In the same vein, the Qur'ān, being a composite of knowledge, originates as a metaphoric gift from Him. ${ }^{57}$ The arguments are equally relevant and useful as objections against the protection of traditional knowledge. As a process concerned with finding solutions to human needs and challenges, traditional knowledge is mainly concerned about creating utility for or deriving benefits from knowledge resources. Thus, while plant and other biological resources are a gift from God, ${ }^{58}$ their value and utility are largely discovered by local communities.

Although traditional knowledge makes use of natural products, the use and value of these products are not found in nature, they result from human intellectual efforts. This is confirmed by studies that found

$56 \quad$ Ida Madieha "Basis for the Recognition of Intellectual Property in Light of the Sharī'ah," International Review of Industrial Property and Copyright Law, Vol. 27, No. 5 (1996): at 650.

$57 \quad$ Ibid, 651.

58 For instance, see Qur’ān, al-An'ām: 99. 
such products result from a constant set of interactions between particular people and their environments. ${ }^{59}$ It should be noted that, traditional knowledge involves skills that are acquired through various ways of knowing including observation, apprenticeship and training. In addition, its holders undergo perseverance to conserve and sustainably utilise biological diversity, the main stay of the knowledge. This diversity serves as a laboratory in which research and experiments on the knowledge are carried out. Conservation and sustainable use of environmental biodiversity involve huge investments of materials, time, energy and psychological efforts, including sacrifice while forbearing discomfort with great difficulty. The question remains whether this kind of investment is sufficient hard work or labour to acquire property rights in Islam.

Shari ${ }^{\prime} a h$ injunctions relating to the acquisition of property by hard work or labour are commonly narrowly construed as referring to physical labour such as hunting, farming, digging or the reclamation of land. Ida-Madieha found this trend among early scholars such as Ibn Khālidun (d. 1406) and other contemporary scholars, including Muhammad Baqer Sadr (1935-1980) who argued that property rights in natural wealth is conferred on a person by his labour. However, she contends that this approach is unjustified and that the term 'labour' should be broadly interpreted to accommodate mental exertions. ${ }^{60}$

Allāh provides gifts of nature including treasures of the earth, sea and air for man's sustenance, ${ }^{61}$ not just to make his life possible but also pleasant and enjoyable. ${ }^{62}$ A full realization of the value of these treasures requires more than the availability of the materials through exertion of human physical energy. The functions, uses and significance of these resources in points of time and space must also be identified. Knowledge empowers mankind to dominate his environment and exploit its resources to resolve his needs and challenges. Therefore, if, as they

$59 \quad$ Nkechi Mgbeoji, "Indigenous Knowledge and its Relationship with Biological Diversity," paper presented at the University of Ibadan (UI) Indigenous Knowledge Study Centre Workshop, held at the UI Conference Centre Ibadan, Nigeria, between 20 ${ }^{\text {th }}$ and 24 $4^{\text {th }}$ April 2009: 26.

$60 \quad$ See Ida-Madieha, "Basis for the Recognition of Intellectual Property ...," at 664 .

61 Qur'ān, al-Baqarah: 29.

62 Qur'ān, al-'Imrān: 191 states: "Our Lord, You have not created this (world and all its wealth) in vain." 
say, wealth is the outcome of interactions between mankind and his surroundings (which includes the earth, its flora and fauna): knowledge is also the key to wealth. Perhaps, in the light of the Prophet's hadith, this is the true reality of the Sharī'ah. The Prophet (SAW) said:

Any person who wants to posses the life of this world should have knowledge; the one who wants to possess the hereafter should have knowledge; and the person who wants to possess both this world and the hereafter should also have knowledge.

The one with knowledge truly has the tool to conquer the world and its treasures. He engages observations and experimentations to discover new uses and functions for world resources and new methods of production. The application of physical energy depends largely on ideational decisions and directions for efficiency. The powers that drive from 'Knowledge' do not come easy. It is a product of rational inquiry and observation - which, in turn, require the great investments of time, skill and energy. The Qur'ân highlights the nature of investments that are involved in the obtaining of power through knowledge. Allāh says: "And those who strive in Our (cause) - We shall guide them to Our paths ....” ${ }^{33}$ The commentary provided by Abdullahi Yūsuf 'Alī on the meaning of 'strive' is very instructive. It states:

"Strive in Our Cause" All that man can do is to strive in Allāh's cause. As soon as he strives with might and main, with constancy and determination, the Light and Mercy of Allāh come to meet him. They cure his defects and shortcomings. They provide him with the means by which he can raise himself above himself. They point out the Way and all the Paths leading up to it.”

Local traditional lifestyles consistent with conservation and a sustainable environment are a great demonstration of this striving accompanied by sacrifice with determination. In the bid to maintain moderate consumption and demonstrate respect for the environment people end up living a poor life. It is probably for this reason some have

63 Qur’ān, al-‘Ankabūt: 69. 
sought to justify benefit payments for access to the biological diversity associated with traditional knowledge as a form of poverty alleviation for people responsible for conservation and the sustainable use of the environment. ${ }^{64}$ It is submitted however, that the benefits of compensation paid to traditional knowledge holders should not merely be regarded as a means to alleviate poverty under the Shari $` a h$. Rather, the people duly earn these payments on account of their right to receive benefits from the fruit of their social, psychological and mental labour represented by their traditional knowledge.

\section{ISLAM AND OWNERSHIP OF RIGHTS IN TRADITIONAL KNOWLEDGE}

In Islam, ownership of everything belongs to Allāh in accordance with His injunction: "And spend (in charity) out of the (substance) whereof He has made you His vicegerent." ${ }^{\prime 65}$ This implies that persons having possession of properties are regarded as mere guardians, custodians or trustees while true ownership of the properties resides in Allāh. In effect, the right of possession is subject to responsibilities imposed by the ultimate owner under the Sharī $a h .{ }^{66}$

According to some contributors, this trusteeship as introduced by the Shari 'ah to property ownership is analogical to the collective rights system since the person(s) in actual possession holds only the right of a priority to use the resources. ${ }^{67}$ Thus, collective rights under Islam are of two types: (i) the collective rights of all to use certain public

\footnotetext{
64 Abd al-Rahman Yousri, "Sustainable Development: An Evaluation of Conventional and Islamic Perspectives" in Islamic Perspective on Sustainable Development, Munawar Iqbal (ed) (New York: Palmgrave Macmillan, 2005), at 23-47.

65 Qur'ān, al-Hadìd: 7.

66 Abd Al-Karīm Zaydān, Al-Madkhal li Dirasat al-Sharī‘atul Islāmiyyah, (Bayrūt: Mu’asasah al-Risālah Nāshirun, 1420AH/2009AD), 229.

$67 \quad$ Zamir Iqbal and Abbas Mirakhin, "The Stakeholders Model of Governance in Islamic Economic System," in Islamic Perspectives on Sustainable Development edited by Munawar Iqbal, (New York: Palmgrave Macmillan, 2005), at 58-89.
} 
resources; (ii) collective claims by all to resources privately held by individuals having the right of priority to use. ${ }^{68}$

The first category refers to resources held as public property whether by government or community for common use by citizens. This category includes water, grass and fire in respect of which the Prophet declared mankind as collective owners: "Men are partners with regard to the use of three things: grass, water and fire." ${ }^{69}$ Although, it seems from this hadith that resources have a status analogous to the 'heritage of mankind' (i.e., are open to common use by humanity), ${ }^{70}$ jurists hold divergent views on the actual legal consequence of the hadith.

One group, including the famous opinion of the Mālikī School, holds that these resources are removed from individual ownership. They are owned by all Muslims in accordance with custom. Thus, they are to be managed by the Imām for the interests of all. ${ }^{71}$ The majority opines that the hadith constitutes an exception to the rule on private ownership. They maintain that the resources are free for common use, and may not become privately owned unless clearly and literally captured. ${ }^{72}$ This type of collective right is analogical to public ownership and is completely different from the type of customary collective right relevant to traditional knowledge.

The second category refers to resources held collectively in trust for Allah but to which private rights may be attached. This type of resource ceases to be strictly collective once an individual applies his creative labour to the resource (i.e. he is the first to do so) and acquires possessory right over it. In effect, such a collective right becomes an individual right subject to other considerations under the Sharī $a h .{ }^{73}$ Being

Ibid.

69 Reported by Ahmad and Abū Dāwūd from Abī Kharash, the latter's report was itself based on the reports of certain companions of the Prophet. See 'Abd al-Hamīd Hamw al-Ba'ly, Al-Milkiyyah wa Dawābituhā fì al-Islām, (Al-Qāhirah: Maktabat al-Wahbah, 1405AH/ 1985 BC), at 30. In another report by Abū Hurayrah, the Prophet is reported to have said that: "There should be no prevention (of the use) of water, fire, or plants.” (Reported by Ibn Majjah), see 'Abd al-Hamīd Hamw, AlMilkiyyah wa Dawābituhā fì Al-Islām, at 30.

71 Ibid.

72 Ibid

${ }^{73}$ Abd Al-Karīm Zaydān, Al-Madkhal li Dirāsat al-Sharī‘atul
} 
originally collective before devolving to the individual, it can be described as a 'collective private right' in contradistinction to the public collective type. The closest example of a collectively held resource is privately held land.

In traditional communities, property is held collectively in accordance with a worldview that property 'belongs to communities or families but never to the individual.' According to this percept, communities or families comprise a number of people out of which many are living, many are dead and others are yet unborn. Thus, all living members are guardians or custodians of the property for the dead and unborn members of the community. The clear difference between this notion of collective ownership and that of a "private collective right" under the Shari'ah, is that the individual does not acquire private proprietary rights to resources because these rights invariably stick to communities or families. But the focus of this rule is limited to immovable and intangible properties. Separate rules apply to ownership of movable properties, ${ }^{74}$ something beyond the scope of this research.

However, this does not imply that individuals are totally disenfranchised under the customary system of collective ownership. The system draws a distinction between collectively held proprietary rights and rights to use held by individuals. Consequently, the individual cannot validly sell or dispose of a collective property without the consent of the head and other principal members of the family. This rule applies to traditional knowledge with equal force because as an intangible property it is held collectively by the communities or sections thereof. The question is whether this principle is valid or consistent with the Sharīah.

The notion or concept of ownership existing under customary law is closely similar to ownership under the Sharī $a h$ in several respects. First, the exercise of proprietary right is subject to spiritual and communal considerations under both systems. In Islam, the exercise of proprietary rights by an individual is subject to the rights of Allah as dictated by the Sharī $a h$. Similarly, present holders of property under customary law are obliged to observe the interests of past and future members of the

Islämiyyah, at 232. The author identifies zakāh as one of the responsibilities attached to individual right over property.

$74 \quad$ For further reading on applicable rules to ownership of movable properties, E. A. Ajisafe Moore, The Law and Customs of the Yoruba People, (M.A. Ola: Abeokuta, 1924), at 12-18. 
communities or families. Thus, the two systems associate ownership with responsibilities.

Second, despite these diverse approaches to the recognition of an individual's interests, the important point is that such interests are ultimately addressed in one way or another. The Shar'iah vests proprietary rights in the individual, while customary law caters for his right to use and enjoy the property. Customary law's arrangement is analogical to the division of property rights under Sharī'ah, into milk almanfa 'ah (ownership of benefit) and haqq al-intifä ${ }^{\prime}$ (right to exploit benefits). ${ }^{75}$ The former (i.e. "ownership" of traditional knowledge) vests in the family or the community, while the latter (right to exploit or use traditional knowledge) resides with individual members. Third, the power to exercise proprietary rights ultimately resides in a particular entity. Whereas the individual is the proprietary unit under the Shari $i a h$, the group holds the power to exercise proprietary right under customary law.

What follows from the foregoing discussion is that both systems seek to provide the individual with the means to enjoy life without compromising the interests of the larger community. Thus the difference between the systems lies in the methods employed to achieve the common goals of facilitating the enjoyment of life by the individual while simultaneously protecting the larger interests of the community. In Islam, the individual has full right over property but this is protected only to the extent that his enjoyment does not undermine the general interests and well being of the community. Islam protects these incidental interests through certain limitations, including circumscribing the absolute right of disposition. ${ }^{76}$

In regard to traditional knowledge, it is difficult to see how an individual can have the power to transfer collectively developed and improved resources without compromising group interests. This makes the customary system of collective rights worthwhile in realizing the aim of the Sharì ah to protect the interests of both the individual and the community. It is probably for this reason that a contributor argues that the stakeholder model of decision-making, which reflects the customary

\footnotetext{
$75 \quad$ Maḥmūd Abū Zahrah, Al-Milkiyyah wa Nazariyyat al- 'Aqd fi Sharī‘ah al-Islämiyyah, at 70.

76 For example, exercise of proprietary of transfer is subject to the neighbor's right of pre-emption under Shuf'ah.
} 
decision-making system, is recognised by the Shari ${ }^{-} a h .{ }^{77}$ Therefore, it is submitted that although collective ownership connotes different arrangements within Sharīah and customary laws, its application is mutually consistent under the systems.

Furthermore, the Islamic institution of waqf is a demonstration that ownership structure under customary law is not strange to the Shari 'ah. Waqf operates on similar principles, if not wholly the same as collective ownership under customary law. In the Sharī'ah, the term refers to a system whereby certain property is held and preserved to serve specified interests, while at the same time prohibiting its use or disposition outside specific objectives. ${ }^{78}$ Waqf is classified into two: waqf al-ahlī (private endowment) and waqf al-khayrī (public charitable endowment). The former appears closer to a property system under customary law since it promotes collective ownership with private status. Although there is no agreement among the jurists regarding the limit of rights held by beneficiaries of this type of endowment, the majority is of the opinion that the property is inalienable either by sale or gift. ${ }^{79}$ The same rule is applicable to "ownership" of traditional knowledge under customary law. This approach also forms the nucleus of traditional knowledge ownership in some Muslim dominated countries as demonstrated by Qatar's submission to the World Intellectual Property Organisation (WIPO). In its National Focal Point on traditional knowledge, the State of Qatar maintains that traditional knowledge is held by way of communal ownership based on customary law. Further, the report acknowledges or confirms that Qatar's modern legal system is based on Islamic law which is mutually compatible with the customary law. ${ }^{80}$

\footnotetext{
$77 \quad$ Iqbal, etal, "The Stakeholders Model of Governance ...," at 68.

78 Sayyid Sābiq, Fiqh al-Sunnah, (Dār al-Fikr: Bayrūt, $2^{\text {nd }}$ edn., 1998), 3:267.

$79 \quad$ Ibid.

80 Supreme Council for the Environment and Natural Resources (SCENR) National report on intellectual Property and traditional knowledge related to genetic resources, Qatar, available online at http:// www.cbd.int/doc/world/qa/qa-nr-abs-en.doc, (retrieved 16 Jan. 2010).
} 


\section{CONCLUSION}

Although there is no direct provision for the treatment of protection of traditional knowledge under the Shari ${ }^{-} a h$, the latter provides a good basis for the protection of the former. There is corresponding treatment of the key elements and features of traditional knowledge protection under the Shari ${ }^{\prime} a h$, which facilitate comparative examination and identification of the existing and potential areas of convergence between the systems.

The nature of traditional knowledge as oral knowledge transmitted from one generation to another simply illustrates the original perception of knowledge in Islam. Even with the advent of writing and other forms of notation, Islam does not cease to recognize this traditional mode as a valid knowledge system as quite a number of knowledge developments in Islam are traced to oral traditions.

In Islam all knowledge belongs to Allāh, but this does not preclude the status of man as the developer of new utilities for knowledge use. God provides everything on earth for man's sustenance, but the levels of understanding the functions and applications of the resources vary among men. The local traditional people gain an edge over urban dwellers in respect of their knowledge of biodiversity and its uses. To that extent, they deserve to be accorded recognition and primacy over their knowledge. Islam recognizes varying perceptions about resources and facilities of life, hence the acknowledgment in the Qur'ann that the people of knowledge cannot be compared with the ignorant.

Under customary law, traditional knowledge is held collectively by the communities or sections thereof. The right is also considered inalienable because it is to remain perpetually with the group. This approach is similar in a way to the Islamic concept of ownership by God, in which case, man occupies the position of vicegerent of Allāh over all properties. Although Islam generally recognizes individual ownership, its emphasis on the need to respect collective interests remains unmistaken. The institution of waqf is a direct equivalent of customary law ownership, both in structure, theory and practice.

The preponderant views of the Jurists seem to support the recognition of traditional knowledge, being a variant of manfa 'ah as a form of $a l-m \bar{a} l$ (property). The chief consideration is that traditional knowledge provides manfa 'ah (benefits), without which nothing is worthy to be regarded as property. Based on this premise, contemporary jurists and contributors have found the argument extendable to intellectual 
property. Traditional knowledge obviously provides some benefits for its holders as well as the general society and is thus worthy of protection as property. Its holders are therefore entitled to enjoy proprietary and other rights (of cultural concerns) as recognized for similar concerns under Islam. 